\title{
The Political Direction of Indonesian Economic Law as the Conception of Welfare State in the 1945 Constitution
}

\author{
Neni Sri Imaniyati ${ }^{*}$ Efik Yusdiansyah, Muhardi, Husni Syam, Mohammad Tahir Cheumar \\ and Panji Adam
}

\section{Universitas Islam Bandung, Indonesia}

\begin{abstract}
Political law, political economy and political economy law are three concepts that arise from a deep understanding of the 1945 Constitution as statutory norms. A series that tries to align the interests and desires of the 1945 Constitution with the interests of the state and the people's wishes, which often have different views and practices between the two. This article aims to analyze the direction of Indonesian economic law politics policy in the Welfare State conception based on the 1945 Constitution. The method used is a normative juridical approach with descriptiveanalytical techniques using qualitative juridical data analysis methods. This article concludes that the direction of Indonesian economic policy shows some adoption of neoliberalism values that have become references in the formulation of monetary policy in Indonesia. As a government law politics, the direction of economic policy must be oriented towards the institutionalization of the status of the Indonesian nation to advance the general welfare. And the "vehicle" for institutionalizing this staatsidee, as formulated in Article 33 of the 1945 Constitution of the Republic of Indonesia, is the concept of a welfare state.
\end{abstract}

Keywords: Politics, Law, Economy, Indonesia.

\section{INTRODUCTION}

Politics, law, and economy in the era of modern countries that adhere to the principles of the nationstate are words that are interrelated with one another. The built relationship starts from a combination of words, namely: economic law, political economy, political law, political economy, political economy law. Combinations of words allow the emergence of ideas, concepts, and theories that provide descriptive and operational interpretations. A variety of dishes commonly appear in understanding economic development that involves the community, entrepreneurs, and the role of the state as a party that can provide directions that positively impact both (entrepreneurs and society).

Political law, political economy, and political, economic law are a combination of words commonly used to show synergistic economic development between the three parties (Iskandar Muda \& Muhammad Kadafi, 2013). The relationship built from these three phrases understands that the concept of development must be viewed from various angles. The role of the government and state institutions is needed to encourage the development process. The rule of law plays a vital role in creating conducive situations and conditions to promote increased economic development (Johanis Don Bosko Sukardan, 2020).

*Address correspondence to this author at the Universitas Islam Bandung, Indonesia; E-mail: nsriimaniyati@gmail.com
Areas that concern the wider community's interests, especially in this context, are the economic sector, which needs public law that considers economic aspects. Things that are very important to note include: a) Research on existing laws, more aimed at the current situation, or aimed at the future because laws that only look at the present situation will soon become obsolete and are an obstacle to the economic development of the country; b) Research on indicators that are part of the early warning system. Good law is the law that gives warning signs of danger before a more serious incident occurs; c) Research on the function of laws to protect the public interest and political interests of the Republic of Indonesia so that we can continue to live as an independent and sovereign country, mainly so that there is no dependence on the economy with other countries; d) Legal guidance that can accelerate the transformation from an agrarian society to industrial society (Johanis Don Bosko Sukardan, 2020).

Indonesia is one of the countries with the principle of a nation-state, trying to take advantage of ideas, concepts, and theories related to community development with an integrated approach with political law, political economy and political economy law. The normatively constructive integration is contained in the 1945 Constitution and clearly and legitimizes community development based on Article 33 Paragraph 4 of the Constitution of the Republic of Indonesia, accommodated by the existence of the principle of togetherness, efficiency with justice, and environmental insight in the Indonesian national economy. 
This article also serves as a guide in implementing Indonesian economic law politics by not denying other parts (preamble and essays) of the 1945 Constitution, which were ratified as statutory norms. Directions can provide legal certainty, healthy freedom, and utility. Law can be a tool in advancing the economy of a nation in the context of the welfare of its people, as long as it is implemented fairly and consistently and can provide legal certainty for the community. Conversely, the law can also be an obstacle to economic progress if the regulations are made unfairly and inconsistently so that legal certainty is not created (Aladin Sirait, 2019).

The political direction of economic law for Indonesia is on thoughts and considerations in the national context and at the global level or at least has a strong influence in the ASEAN region (Association of Southeast Asian Nations). The influence is based on respect for welfare, prosperity, benefit and justice for society, as the embodiment of the Preamble to the 1945 Constitution, which is the background for the emergence of a typical Indonesian economic democracy.

Reference to see the direction that the political economy of Indonesian law wants and wants, starting from a proportional interpretation in interpreting the 1945 Constitution, which can be carried out through a descriptive approach. An approach that tries to explain clearly the will of the 1945 Constitution towards political, legal and economic behaviour which is a tool in achieving prosperity and welfare that is socially just.

\section{METHOD}

The research method in this article is normative juridical. The normative juridical approach is deductive research starting from analyzing themes in statutory regulations and examining theories, concepts, principles, and laws related to the political economy in Indonesia. This research is descriptive-analytical; namely, the results of this study are expected to provide a comprehensive, systematic and in-depth picture of a situation or phenomenon being studied regarding all matters relating to the political economy in Indonesia. The research results were analyzed juridically qualitatively to produce descriptive data, then analyzed to obtain answers to the main problems under study. The nature and form of this research report is descriptive analysis; that is, from the literature study it is analyzed to obtain clarity on the subject matter.

\section{RESULTS AND DISCUSSIONS}

\section{The Dynamics of Indonesian Legal Politics}

Political law is an inseparable part of the development of the state in terms of the nation-state, which emerged in the late 19th and early 20th centuries, or emerged from the revolution carried out by nations undergoing European colonialism. The process that changed Dutch East Indies colonialism into an independent Indonesia and became part of the changes in the geopolitical map of the world community which began to develop its legal politics, without denying the influence of the Dutch Colonial Government, which entered the end of its colonial power in the mid-20th century.

The legal politics that was formed simultaneously as the birth of the nation-state began to look for the correct form or at least a proportional one. The search for this form is unlikely to have emerged without preceded by an understanding that shows the bond between politics and law. Etymologically, the term political law is an Indonesian translation of the Dutch legal term rechtspolitiek, formed from two words, namely Recht and politiek (Imam Syaukani and A. Ahsin Thohari, 2011).

According to Bellefroid, the definition of legal politics that refers to the word rechtspolitiek is part of legal science that examines changes in the applicable law that must be carried out to meet the new demands of people's lives. In contrast to Bellefroid, Lemaire argues that legal politics is part of legislative policy and political science in general. Political law examines how the proper legal stipulation (ius constituendum) does not stop at the study of the applicable law (ius constitutum) (Abdul Latif and Hasbi Ali, 2011).

The relationship between politics and law has several possibilities for which party is more determinant of the two. The intersection of law and politics allows the emergence of several alternatives, including that the law determines politics because political activities are regulated by and must be subject to legal rules. Politics also will enable it to be considered more determinant of law because the law is a crystallization of political wills that interact and even compete. Finally, politics and law are understood as social subsystems that are in a balanced position between the two because although the law is a product of political decisions, once the law is created, all political activities must obey and obey legal rules (Laili Bariroh, 2012). 
The combination of the two words was then poured out by Padmo Wahjono (1986) by defining legal politics as the basic policy that determines the direction, form and content of the law to be formed. The definition, which Padmo Wahjono (1991) then reaffirmed by directing legal politics, was linked to the policies of state administrators regarding what the criteria for punishing something were. In this case, the policy can be related to the formation of law, application of the law and enforcement itself.

The definition presented by Padmo Wahjono does not directly indicate the subject or party that has the authority to form and implement policies in legal politics. Soedarto then completed the purpose by designating an institution that was given power by the state, which was directly related to legal politics. Soedarto then explained further that policy in legal politics stems from state agencies authorized to determine the desired regulations, which are expected to express what is contained in society and achieve what it aspires to be (Soedarto, 1983).

Another element conveyed by Soedarto (1986) in terms of legal politics is related to efforts to realize reasonable regulations according to circumstances and situations at one time. Soedarto's view on the notion of legal politics has at least four elements that guide legal politics to have legal legality and political aspirations, including a) state institutions; b) authority; c) the rule of law; d) society; e) policy direction.

Soedarto's definition, which emphasizes the participation of state institutions in determining the legal politics of a country, is narrowed by Soenaryati Hartono (1991) by directly appointing the executive as an institution that has authority by placing legal politics as the means (tools) to implement the desired and implemented national legal system to realize the ideals of the Indonesian nation. Satjipto Rahardjo shortened the definition (2000), emphasizing the means to be selected and used while remaining oriented or placing legal politics in the community's interests as its primary foundation.

Abdul Hakim Garuda Nusantara developed a political law definition in implementing and implementing policies that emerged from socialoriented legal politics, with a critical attitude towards the law that a particular government was trying to implement or implement (Moh Mahfud MD, 2010).

Moh Mahfud MD (2010) states that legal politics is interpreted as an official direction or line that is used as a basis for action and a way to make and implement laws to achieve the nation's goals and state. The definition of legal policy includes making and enforcing the law, showing the nature and direction in which the law will be built. Political law provides the basis for forming a more appropriate regulation, the situation and conditions, the culture and values that develop in a society by considering the community's needs for the law itself.

A different narrative was conveyed by William Zevenbergen (Abdul Latif and Hasbi Ali, 2011). Still, it has the same intention that legal politics tries to answer the question, which legal regulations should be made law. The legislation itself is a form of legal politics (legal policy). The political law in question is the current situation in Indonesia, following the principle of consideration (hierarchy) of the law itself or in Logeman's terminology (Regen, 2006).

\section{The Development of the Dynamics of Political Economy in Indonesia}

Economic policies are actions intended to influence or control economic behaviour. Monetary policies are usually implemented and administered by the government. Examples of economic policies include government spending and taxation, the redistribution of income from rich to week, and the money supply. The effectiveness of monetary policy can be assessed in two ways: positive and normative.

Political economy are specific actions taken or carried out by the government to achieve predetermined goals (for example, in the Indonesian state as stated in the GBHN) as follows: 1) improving the welfare of the population or community members; 2) guaranteeing the enforcement of law and public order (law and order), guaranteeing freedom of opinion and choice; 4) reduce social tensions; 5) defend against outside "attacks"; and 6) providing adequate health and education facilities (Mubyarto, 1999).

Political economy, in the view of Dirk Rubbelke and Stine Aakre, is a government policy that directs the fulfilment of public interests in the economic sector, with three primary objectives of general economic policy: a) formation of efficient resource allocation; b) achieving the desired distribution of income and wealth, and c) economic stabilization (guaranteed price level stability and full employment) (Dirk Rubbelke \& Stine Aakre, 2009).

Political economy can be defined as a policy that emerges based on two economic principles, which form 
the basis for the emergence of economic policies aimed at fulfilling the interests of society as the ultimate goal of the emergence of these economic policies. The two principles are monetary and fiscal.

Sunanda Sen and Zico Dasgupta try to show that monetary and fiscal play an essential role in building a political economy, both of which have an attachment in building the economy of the people relying on inflation targeting as the primary tool to achieve financial stability and targeting growth and job opportunities (Keynesian) (Sunanda Sen \& Zico Dasgupta, 2014).

Alan S. Blinder and Alan B. Krueger (2004) show that five elements of an economic policy can be categorized as political economy. These elements are the principles underlying economic development directed at the public interest by utilizing public opinion to measure and see the fulfilment of the public interest. These elements include a) Taxes; b) Deficit in the expenditure budget; c) Minimum Wages; d) Social security; e) Health insurance.

Alan S. Blinder and Alan B. Krueger further demonstrate the interplay of politics and economics in determining the direction of political economy to be built in the economic system: a) political mechanisms make almost all crucial economic policy decisions, and b) decisions of elected politicians heavily influenced by public opinion polls. This is not a very dazzling insight.

Political economy, in short, is part of state and economic policies related to DNOS / Distribution Network Operators. Political economy is defined as a livelihood in society in organizing and directing the flow of reproduction within the country, focusing on 1) fiscal, 2) income; 3) monetary; 4) economic policy. The concept of political economy in the realm of economic theory is used to show two phenomena: a) as the diversity of activities of the state and other economic and political decision-makers (i.e. macroeconomic subjects), which aim to create a good social environment for optimal and economic development; $b$ ) as a scientific discipline in the economic science system that discusses finding and analyzing relationships and patterns about the functioning of the state and other macroeconomic subjects in regulating economic relations (Ljiljana Stošić Mihajlović, 2015).

Political economy can also be interpreted as policies in the economic sector directly related to trade, fiscal and monetary, public and private sectors, the business environment. Policies that give rise to optimism to improve the quality of the workforce as a partner in overcoming and reducing unemployment, as well as increased compensation for work to lift the workforce's economic capacity from poverty (Gouda Abdel-Khalek, 2010).

Poverty is tried to be reduced through the following principles: a) decent work as a productive factor; b) a macroeconomic framework that supports employment; c) entrepreneurship and private investment; d) increase the opportunities and productivity of the working poor; e) end discrimination in the labour market; f) environmentally and socially sustainable growth; and g) employability and adaptation (Global Employment Agenda, 2010).

Political Economy in the Indonesian context can be seen from the historical trajectory of the preparation of Article 33 of the 1945 Constitution, as a big idea coined by Moh. Hatta and Soepomo assisted and directed the birth of the principles that underlie the legal system and politics for economic life in Indonesia. The principles that are meant are a) the principles of joint and family business which underlie the financial system in Indonesia; This principle is contained in Article 33 paragraph (1) of the 1945 NRIT Constitution, which talks about the economic structure following the soul and personality of the Indonesian nation. The economic structure referred to by this provision is not seen as an independent thing but is a part of social welfare. This principle also rejects the concept of individualism in the economic field because the welfare of society is prioritized. In other words, the principles of justice, protection, and the principles of kinship are implied in this principle; b) principles of economic democracy; We can see this principle from the explanation of Article 33 of the 1945 Constitution of the Republic of Indonesia in the first and second paragraphs. As for the explanatory statement of Article 33 , as a whole, it is stated as follows: In Article 33, it is noted that the basis of economic democracy, production is carried out by all, for all under the leadership or supervision of community members. It is the prosperity of society that takes precedence, not the prosperity of the individual. Therefore the Economy is structured as a joint effort based on the principle of kinship. Build a company following that is cooperative. The Economy is based on economic democracy, prosperity for all. Therefore, production branches that are important to the state and which affect the people's livelihoods must be controlled by the state. If not, the reins of production will fall into the hands of people in power and the people who have been oppressed a lot. Only companies that do not 
control the lives of many people may be in the hands of individuals. The earth and water and the natural resources contained in the planet are the principles of the people's prosperity. Because the state must control it, this principle implies an insight that economic activities in Indonesia are from all, by all, and for all, even under the ownership of members of society; c) the principles of the welfare state; We can see this principle from the contents of the provisions of Article 33 along with its explanations (paragraphs 2 and 3 ) which emphasize the importance of the participation of the state in intervening in economic life and the nation's potentials concerning the lives of many people. The active role of the state (c.q. the Government) is solely aimed at creating welfare for all Indonesian people. The principles above show the view that "economic structure is not a goal, but as a function or a vehicle towards the purpose of the state to create a society that is prosperous, just and prosperous, both materially and spiritually. In other words, economic democracy is not the main/final goal. Still, it is an essential bridge in realizing the society mandated in the fourth paragraph of the Preamble of the 1945 NRIT Constitution and its various elucidations as stated in each GBHN (Asep Bambang Hermanto, 2018).

\section{The Development of Political Economic Law in Indonesia}

Law in modern countries serves three critical roles of government. First, through laws and legal institutions which state that they seek to order the behaviour of individuals and organizations so that economic and social policies are transformed into results. Second, the law defines government structure by collecting its powers, establishing and distributing authority and influence among government actors and between the state and citizens. And third, the law also serves to order contestation by providing the necessary substantive and procedural tools to promote accountability, settle disputes amicably, and change the rules.

The three roles of law can be associated with political, economic regulation in Mubyarto (1999) view related to the Economic Strategy or the Economic Development Strategy. Suppose political economy involves government action or intervention in the financial field to achieve specific predetermined goals while achieving these objectives. In that case, various policy instruments are available, and then the strategy is the decision to choose one or more of the existing policy instruments. Usually, in the economic sector, the following five policy instruments are mentioned: a) Public finance, which is about. government revenue and expenditure (APBN and Taxation); b) Money and credit; c) Value, exchange (rate) currency; d) Direct controls. For example, setting prices, and e) Changes in the institutional framework.

Political, economic law is an effort to improve people's welfare, with welfare, not an abstract concept but an actual condition that directly concerns daily life. Welfare emphasizes the fulfilment of basic needs such as clothing, food, shelter, education, and income that can support the family properly, hoping that this income will increase from time to time. Welfare which is stated clearly and decisively through the constitutional approach is widespread uncertainty in the economy. Delay is related to the meaning contained in the concepts of the economic system, economic order and economic constitution (Kukuh Fadli Prasetyo, 2012).

The encouragement of economic constitutionalism in the politics of economic law that arises from uncertainty about economic growth and stability is part of the importance of placing the economy based on the staatsfundamental norm, which directly regulates and directs the behaviour and financial system of a country. The reference that can be addressed to economic conceptualism by looking at one of the EU-Consent policy papers is stated, "The goal of the economic constitution is promoted relative, i.e. optimal in the given economic circumstances welfare and the economic safety of the citizens" (Jimly Asshiddiqie, 2010).

In line with the importance of the constitution as a basis for determining, formulating and implementing economic law politics to avoid legal uncertainty that hurts the economy, according to Erman Rajagukguk, there are three factors. First, the hierarchy of laws and regulations does not function and still clashes between material-regulated material; second, the apparatus is weak in implementing the rules; and third, the settlement of disputes in the economic sector cannot be predicted. Erman Rajagukguk continued that changes in the politics of economic law can be carried out with reflexivity through manageable, available, workable, and interwoven steps easily with all aspects of social life; if this is not done then, economic law will increasingly be altered in society, as is currently happening (Nike K. Rumokoy, 2010).

The view that directs the constitution as a fundamental norm in the welfare state is included in the 
basic idea of constitutional law politics. In simple terms, legal politics can be interpreted as economic policy based on the constitution in the context of a welfare state, referring to the active role of the state in managing and organizing the economy, which includes the state's responsibility to ensure the availability of essential welfare services at a certain level for its citizens (Darmawan Tribowo and Sugeng Bahagijo, 2006).

In line with these essential welfare services, Ross Cranton defines the welfare state as a state that determines the minimum standard of social welfare. In many countries, the essence of the welfare state is borne by the minimum requirements guaranteed by the state, namely: income, food, health, housing and education (Safri Nugraha, 2004).

The concept that affects the legal product is divided into two characters, namely responsive and conservative. Responsive legal products, namely those whose characters reflect the fulfilment of the demands of individuals and various social groups in society, are expected to reflect justice. Furthermore, conservative legal products are good products that reflect the political vision of the holders of power so that their actions do not earnestly invite community participation and aspirations (Mu'Adil Faizin, 2017).

Louis Kaplow and Steven Shavell Fokus classified at least four main elements that include the principles in the political economy of law: First is the central area of civil law, related to responsibility for accidents, which can be understood as overcoming the problem of probabilistic externalities. Second, property law concerning the nature and justification of property rights can be obtained, transferred and resolved if there is a dispute. Third, laws relating to agreements (contracts), including the formation of contracts, interpretations, and solutions to violations of the deal. Fourth, civil litigation is related to the rights which are disturbed due to violations of the rule of law that are private and public. Fifth, public law enforcement focuses on law enforcement efforts, the magnitude of sanctions, and other issues relevant to criminal law (Louis Kaplow and Steven Shavell, 1999).

The judiciary is another essential part of the political terminology of economic law. McNollgast argues that judicial independence is not a constant feature of a particular legal system and is vulnerable to fluctuations that reflect the political composition of the branches of government. It is essential to protect the independence of the judiciary, as the independence of the court is more significant under a decentralized government than under a more centralized government. This causes the centralized government to allow the executive and legislature to coordinate to undermine judicial decisions (Nandini Ramanujam, Mara Verna, Julia Betts, Kuzi Charamba, and Marcus Moore, 2012).

Political, economic law also contains the meaning of law in society, including integrating and coordinating (financial) interests, which can overlap one another and by statute are combined so that the problem of overlapping regulations can be minimized. Organizing these interests is done by limiting and protecting these interests. Indeed, in traffic of goods, protection of specific interests can only be done by modifying the interests of the other party (Zulfi Diane Zaini, 2015).

\section{Direction of The Development of Political Economic Law in Indonesia}

The basic concept of Indonesian Economic Development Law is Indonesian Economy in the sense of development and enhancement of national economic resilience at a macro level. Meanwhile, the rationale for the Social Economic Law is the humane economic life of Indonesia and equal distribution of income, where every Indonesian citizen has the right to a decent life and work. In this connection, all efforts for economic development in Indonesia aim to create the Welfare of every Indonesian citizen so that Indonesia's economic development must uphold fundamental human rights (Sunaryati Hartono, 1988).

Law in the economic development of a country has a critical legal position and role. Jean Jacques Rousseau gave his opinion in 1755 , in A Discourse on Political Economy, describing the relationship between law and Economy. The world economy itself comes from Oikos, which means household, and nomos which means law. Rousseau continues with the phrase, "Only the wise and legitimate government of the house for the common good of the whole family. The meaning of the term was then extended to the government of that great family, the State. "Even further, Per Krussel and Jose Victor Rios Rull stated that there is a close relationship between economic growth and the democratic and constitutional process (Jimly Asshiddiqie, 2010).

A comparison material that law, politics and Economy can become a legal product that is valuable as a policy that all citizens must obey. The political 
position of law literally in a country's economy is like a symbiosis of interrelated mutualism. If legal politics is carried out, it means that economic policy reform will occur indirectly. Legal development must show that development must be a means of legitimacy and safeguards for economic development (Mardalena Hanifah, 2012).

The relationship between the three cannot be separated from the constitution, which provides direction for the continuation of political, legal and economic development and growth in a country. The body, known in Indonesia as the 1945 Constitution (UUD 1945), the narratives contained in it become the main direction in building the politics of economic law in Indonesia. The relationship which will be a benchmark for whether or not to carry out the objectives that have been directly written and described from the preamble to the 1945 Constitution: "Then rather than that to form an Indonesian state government that protects the whole Indonesian nation and all the blood of Indonesia and to advance the general welfare, educating the nation's life, and participating in implementing world order based on freedom, eternal peace and social justice, ....."

The preamble to the 1945 Constitution provides a clear note and description regarding the political direction of Indonesian economic law in the form of the main objective of any policy that is to build Welfare in the economic sector through the rule of law, based on the desire to realize social justice which is directly proportional to its nature, namely to provide prosperity to all Indonesian people. Welfare with the characteristics of a) constitutional protection, in the sense that the constitution in addition to guaranteeing individual rights must also determine the procedural way to obtain the protection of the guaranteed rights; $b$ ) independent and impartial tribunals; c) free elections; d) freedom of expression; e) freedom to associate/organize and oppose; f) civic education; g) people's economic system (SF. Marbun and Moh. Mahfud MD, 2009).

This is one reason why developed countries try to reduce this gap by implementing a welfare state. A system that gives a more significant role to the State (government) in the development of planned, institutionalized and sustainable social Welfare (SF Marbun, 2001).

In simple terms, the political economy of Indonesian law, by taking into account the 1945 Constitution, is directed at the fulfilment of the following principles: a. Mutual Principle. With the existence of the principle of togetherness in Article 33 Paragraph (4), the focus of kinship in Article 33 Paragraph (1) of the 1945 Constitution of the Republic of Indonesia must be understood in a broad sense, no longer in an organic substance, in the form of economic actors who are must be in the form of a cooperative in the narrow sense of a business entity. In addition, with the existence of the principle of togetherness, the focus of kinship is not abused about the notion of a family system which has negative connotations as reflected in the practice of corruption, collusion and nepotism (KKN) in the New Order era (Elli Ruslina, 2019).

b. The Principle of Equitable Efficiency. According to Mardiasmo (Jeane Neltje Saly, 2008), efficiency is the achievement of maximum output with specific inputs. Input is a resource that is used for the implementation of a policy, program or activity. Meanwhile, the outcome is the result achieved from a policy, program or activity. In Article 33 Paragraph (4) of the 1945 Constitution, the principle of efficiency is combined with the principle of justice. The existence of this efficiency principle has sparked mixed responses from several scholars. One of them is Didiek J. Rachbini, who said that although this efficiency principle can provide a faster rate of economic growth, the efficiency principle contains an element of competition with negative externalities. The addition of Article 33 Paragraph (4), which includes the new regulations, is intended so that the Constitution's provisions are not misused because that is not the case. Pancasila and the 1945 Constitution of the Republic of Indonesia call for a balance in all aspects of state life. The idealized balance also includes a balance between competition and cooperation and between principles that prioritize efficiency, but on the other hand, must guarantee justice. Furthermore, it is related to accommodate the doctrine of fair efficiency. Efforts must also be made to the law to accommodate new ideas and be adapted to changing conditions if it is to obtain the highest level of efficiency. The performance of institutions that are not suitable for increasing efficiency must be immediately optimized not to become obstacles to economic activity. To accommodate these needs, legal institutions must play an essential role in adapting to the 
conditions of ideas and conditions that are rapidly developing (Adi Sulistyono, 2007).

c. Sustainable and Environmental Friendly Principles. There are two concepts related to the idea of ecosystems, namely that the national economy based on democracy must contain the principles: (i) sustainability and (ii) environmentally sound. By itself, the entire ecosystem, as referred to in Article 33 Paragraph (3) as interpreted extensively and creatively by various laws in the environmental sector, must be managed for the benefit of development based on sustainable development principles and environmentally sound (pro-environment). (Mira Rosana, 2018).

d. Principles of Independence and Maintaining a Balance of Progress and National Economic Unity. The principle that is no less important is independence and maintaining the balance of progress and national economic unity. The world economy is interdependent as a necessity, which is indisputable. This normative principle of autonomy requires not being trapped into dependence, debt, investment, and so on. Thus, all laws in the investment sector, which are instruments to encourage investment, must be outward-looking. However, it still places the government that is sovereign over Indonesia's natural resources and can regulate according to the interests of the Indonesian people (Ali Rama dan Makhlani, 2014).

According to Suharsono Saqir, the politics of economic law should not come out of the principle of social economy, which according to Suharsono Saqir, is reflected in the direction of triple track development, namely pro-poor, pro-jobs and pro-growth. Six benchmarks can be used to assess the success or failure of a development process, from the triple track development, namely: a) The people are free from poverty with a quality economic growth rate; b) The people are free from ignorance and become productive human capital; c) People are free from unemployment and work creatively and productively to increase their own and other people's income; d) The country is free from dependence on foreign debt; e) The country is free from a shortage of foreign exchange because the value of exports exceeds imports; and f) The country is free from ecosystem damage so that development can be developed in a sustainable manner (Udiyo Basuki, 2014).
The linkages that arise from the meaning of welfare in resolving social problems through political, economic law can also be based on 6 (six) concepts as expressed by J D. Nyhart (Satjipto Rahardjo, 2007), namely: first, predictability. The law must have the ability to provide a definite picture in the future of the situation or relationships that are carried out in the present. Second, procedural skills. Guidance in the field of procedural law allows material law to realize itself properly. Third, codification of goals. Legislation can be seen as a codification of the goals and objectives as desired by the state. Fourth, the balancing factor. The legal system must become a force that balances conflicting values in society-fifth, accommodation. Rapid changes in effect will cause an extended loss of balance, both in relationships between individuals and groups in the community: sixth, the definition and clarity of status. In addition to the legal function that provides predictability, it can be added that the legal process also provides clarity regarding the status of people and goods in society.

Economic development dramatically affects the level of prosperity of a country. However, economic growth that is entirely left to the market mechanism will not automatically bring prosperity to all levels of society. The experience of developed and developing countries proves that although the market mechanism can produce optimal economic growth and employment opportunities, in its development, these developed countries generally fail to create income distribution and solve social problems (Ridwan HR, 2006).

\section{CONCLUSION}

The realization of prosperity, welfare, and social justice for the community is part of the state's mandate. Mandate embodied in politics, law and economics. Wordiness that shows the presence of the state as the manager of the interests of the community The goods that are formed in the formulation of political law, political economy and political economy law. These three combinations of words are the steps and behaviour of the state to guide and show the direction to achieve the will of the 1945 Constitution in fulfilling the rights contained therein. Legal politics tries to bring up every policy that comes from the state, based on the public interest, which is fulfilled through legal rules that reflect order, security and comfort. Political economy is related to economic development directed not at one side. Still, two sides of interest-the government's interests as managers of community needs fundamental or essential in fulfilling them. The interests 
of the community as the party whose needs are managed can obtain these basic needs. The political law of the Indonesian economy deals with economic development through governance with the rule of law as the legality of policies that can encourage economic growth and development that directs the achievement of social welfare. In the definition of the whole of Indonesian culture, society is not limited to specific groups or groups.

\section{REFERENCES}

Abdul Latif dan Hasbi Ali, Politik Hukum, Sinar Grafika, Jakarta, 2011.

Adi Sulistyono, Pembangunan Hukum Ekonomi Untuk Mendukung Pencapaian Visi Indonesia 2030, Pidato Pengukuhan Guru Besar Hukum Ekonomi Pada Fakultas Hukum Universitas Sebelas Maret Surakarta, disampaikan dalam Sidang Senat Terbuka Universitas Sebelas Maret Surakarta Pada tanggal 17 Nopember 2007.

Aladin Sirait, Peranan Politik Hukum Investasi Dalam Pembangunan Ekonomi Indonesia, Politea: Jurnal Kajian Politik Islam Vol. 2 No. 1 Januari - Juni 2019. https://doi.org/10.20414/politea.v2i1.1341

Alan S. Blinder and Alan B. Krueger, What Does the Public Know about Economic Policy, and How Does It Know It?, CEPS Working Paper No. 99 May 2004. https://doi.org/10.3386/w10787

Ali Rama dan Makhlani, Analisis Kesesuaian Konstitusi Ekonomi Indonesia Terhadap Ekonomi Islam, Al-IQTISHAD: Jurnal IImu Ekonomi Syariah (Journal of Islamic Economics), Vol. 6 No. 1 Januari 2014 https://doi.org/10.15408/ijies.v6i1.1367

Asep Bambang Hermanto, Politik Hukum Dalam Demokrasi Ekonomi Indonesia, SELISIK - Volume 4, Nomor 7, Desember 2018.

CFG. Sunaryati Hartono, Hukum Ekonomi Pembangunan Indonesia, Bina Cipta, Bandung, 1988.

Darmawan Tribowo dan Sugeng Bahagijo, Mimpi Negara Kesejahteraan, Pustaka LP3ES, Jakarta, 2006.

Dirk Rubbelke \& Stine Aakre, Objectives Of Public Economic Policy And The Adaptation To Climate Change. Journal of Environmental Planning and Management. Vol. 532009. https://doi.org/10.1080/09640568.2010.488116

Elli Ruslina, Asas Kebersamaan Dan Kekeluargaan Sebagai Dasar Pembangunan Hukum Ekonomi Indonesia. Jurnal Hukum Sasana, Vol. 5 No. 2, November 2019. https://doi.org/10.31599/sasana.v5i2.99

Global Employment Agenda, International Labour Office, Geneva, 2003.

Gouda Abdel-Khalek, Growth, Economic Policies and Employment Linkages in Mediterranean Countries (The cases of Egypt, Israel, Morocco and Turkey), Employment Sector Employment Working Paper No. 63 2010, International Labour Office, Geneva, 2010.

Imam Syaukani dan A. Ahsin Thohari, Dasar-dasar Ilmu Politik, Cet. VII, RajaGrafindo Persada, Jakarta, 2011.

Iskandar Muda \& Muhammad Kadafi, Penerapan Konsep Hukum Pembangunan Ekonomi Dalam Upaya Pencegahan Eksploitasi Pekerja Alih Daya (Kajian Putusan Mahkamah Konstitusi Nomor 27/PUU-IX/2011), Jurnal Yudisial Vol. 6 No. 1 April 2013.

Jeane Neltje Saly, Laporan Akhir Tim Kompendium Bidang Hukum Ekonomi Kerakyatan, Badan Pembinaan Hukum Nasional Departemen Hukum Dan Ham RI, Jakarta, 2008.
Jimly Asshiddiqie, Konstitusi Ekonomi, Penerbit Buku Kompas, Jakarta, 2010.

Johanis Don Bosko Sukardan, Pengaruh Politik Hukum Terhadap Pembangunan Ekonomi Nasional, Jurnal Education and development Institut Pendidikan Tapanuli Selatan Vol.8 No.3 Edisi Agustus 2020

Kukuh Fadli Prasetyo, Politik Hukum di Bidang Ekonomi dan Pelembagaan Konsepsi Welfare State di dalam UndangUndang Dasar 1945, Jurnal Konstitusi, Volume 9, Nomor 3, September 2012.

Laili Bariroh, Politik Hukum Nasional Dan Hegemoni Globalisasi Ekonomi, Jurnal Review Politik Volume 02, No 2, Desember 2012.

Ljiljana Stošić Mihajlović, Conditionality Eco Nomic Policy And Economic System, (JPMNT) Journal of Process Management -New Technologies, International Vol. 3, No.1, 2015.

Louis Kaplow and Steven Shavell, Economic Analysis of Law, in A.J. Auerbach and M. Feldstein, Handbook of Public Economics, Harvard Law School and National Bureau of Economic Research, Cambridge, 1999.

Mahfud MD, Membangun Politik Hukum, Menegakkan Konstitusi, Pustaka LP3ES, Jakarta, 2006.

Mahfud MD, Membangun Politik Menegakkan Konstitusi, Rajawali Pers, Jakarta, 2010.

Mahfud MD, Politik Hukum Di Indonesia, Rajawali Pers, Jakarta, 2009.

Mardalena Hanifah, Arah Kebijakan Hukum Politik Ekonomi, Jurnal IImu Hukum. Vol. 3 No. 2, Agustus 2012.

Mira Rosana, Kebijakan Pembangunan Berkelanjutan Yang Berwawasan Lingkungan di Indonesia, Jurnal KELOLA: Jurnal IImu Sosial Vol 1 No 1 Tahun 2018.

Mu'Adil Faizin, Politik Hukum Ekonomi Syariah Di Indonesia Tahun 2008-2017, ADZKIYA Jurnal Hukum dan Ekonomi Syariah, Vol. 05 Nomor 2, September 2017.

Mubyarto, Sistem Dan Politik Ekonomi Berjiwa Kerakyatan, JEP Vol. 4 No. .2. 1999

Nandini Ramanujam, Mara Verna, Julia Betts, Kuzi Charamba, Marcus Moore, Rule of law and economic development:A Comparative Analysis of Approaches to Economic Development across the BRIC Countries, Rule of Law and Economic Development Research Group - ROLED, Montreal, December 2012. https://doi.org/10.2139/ssrn.2389074

Nike K. Rumokoy, Strategi Pembangunan Hukum Ekonomi Indonesia, Jurnal Hukum Unsrat Vol.XVIII No. 5 September Desember 2010.

Padmo Wahyono, Indonesia Negara Berdasatkan Atas Hukum, Cet. II, Ghalia Indonesia, Jakarta, 1986.

Padmo Wahyono, Menyelisik Proses Terbentuknya PerundangUndangan, Forum Keadilan, No. 29 April 1991

Regen, B.S, Politik Hukum, Utomo, Bandung, 2006.

Ridwan HR, Hukum Administrasi Negara, Raja Grafindo Persada Jakarta, 2006.

SF Marbun, dkk, Dimensi-Dimensi Pemikiran Hukum Administrasi Negara, UII Press, Yogyakarta, 2001.

SF. Marbun dan Moh. Mahfud MD, Pokok-pokok Hukum Administrasi Negara, Liberty, Yogyakarta, 2009.

Safri Nugraha, Privatisation of State Enterprises in The 20th Century: A Step Forwards or Backwards? Institute of Law and Economic Studies Faculty of Law University of Indonesia, Jakarta, 2004.

Satjipto Rahardjo, Hukum dan Masyarakat, Penerbit Angkasa, Bandung, 1980.

Satjipto Rahardjo, IImu Hukum, Citra Aditya Bakti, Bandung, 2000. 
Soedarto, Hukum Pidana dan Perkembangan Masyarakat dalam Kajian Hukum Pidana, Sinar Baru, Bandung, 1983

Soedarto, Hukum dan Hukum Pidana, Alumni, Bandung, 1986.

Sunanda Sen \& Zico Dasgupta, Economic Policy in India: For Stimulus, or for Austerity and Volatility?. PSL Quarterly Review 2014.

Sunaryati Hartono, Politik Hukum Menuju Satu Sistem Hukum Nasional, Alumni, Bandung, 1991.
Udiyo Basuki, Hukum, Ekonomi Dan Kesejahteraan: Telaah Yuridis Atas Dinamika Pengaturan Dan Implementasi Pasal 33 UUD 1945, Al-Mazahib, Volume 2, No. 1, Juni 2014.

Zulfi Diane Zaini, Kedudukan Hukum Ekonomi Indonesia Dalam Perspektif Globalisasi Perdagangan, Buletin Hukum Kebanksentralan • Volume 12, Nomor 1, Januari - Juni 2015.

Received on 30-06-2021

Accepted on 13-08-2021

Published on 23-08-2021

https://doi.org/10.6000/1929-4409.2021.10.151

(C) 2021 Imaniyati et al.; Licensee Lifescience Global.

This is an open access article licensed under the terms of the Creative Commons Attribution Non-Commercial License (http://creativecommons.org/licenses/by-nc/3.0/) which permits unrestricted, non-commercial use, distribution and reproduction in any medium, provided the work is properly cited. 